\title{
EFFECT OF THE GROWTH ENVIRONMENT ON CELL-ENVELOPE COMPONENTS OF ESCHERICHIACOLI IN RELATION TO SENSITIVITY TO HUMAN SERUM
}

\author{
P. W. Taylor, P. Messner* and R. Parton $\dagger$ \\ Department of Microbiology, The University, Leeds LS2 9JT, *Sandoz Forschungsinsti- \\ tut, Brunner Strasse 59,A-1235 Vienna, Austria and †Department of Microbiology, \\ University of Glasgow, Garscube Estate, Bearsden, Glasgow G61 1QH
}

Plate I

SUMmaRY. Three smooth strains of urinary Escherichia coli were grown in a chemostat under carbon-limited (C-lim) and magnesium-limited (Mg-lim) conditions over a range of dilution rates (D). Strain LP1674 was resistant to human serum under $\mathrm{C}$-lim but became sensitive when grown under $\mathrm{Mg}$-lim, the degree of sensitivity increasing as D increased. The transition to serum sensitivity was accompanied by loss of ability to produce extractable $\mathrm{K} 1$ antigen and a reduction in the amount of a $46 \mathrm{k}$ envelope polypeptide. C-lim cells of strain LP729 exhibited a delayed sensitive response to serum, the degree of lag in serum killing becoming less pronounced with increasing values of $\mathrm{D} ; \mathrm{Mg}$-lim cells were more sensitive with little or no lag in serum killing. The degree of lag appeared to be directly related to the amount of the $\mathrm{O}$ side-chain sugar mannose associated with the lipopolysaccharide. C-lim and $\mathrm{Mg}$-lim cultures of $E$. coli strain LP1395 were resistant to serum except when growing at near maximal rates. Although $\mathrm{C}$-lim cultures contained more acidic polysaccharide than $\mathrm{Mg}$-lim cells, transition to serum sensitivity did not appear to be related to exopolysaccharide production. Rapidly growing cells of strain LP1395 did, however, have lower lipopolysaccharide 0 side-chain sugar:core-sugar ratios than more slowly growing cells. With all three strains, changes in dilution rate and in the nature of the limiting nutrient were accompanied by changes in envelope protein composition.

This study demonstrates that many cell-surface changes occur in response to alterations in the growth environment and some of these may be correlated with changes in sensitivity to serum.

\section{INTRODUCTION}

Division rates of enterobacteria in animal tissues are much lower than those in laboratory batch cultures (Smith, 1977) and it can thus be inferred that 
bacteria growing in vivo are limited by the availability of essential nutrients. Furthermore, there is evidence that bacteria growing in vivo may display characteristics that are not apparent when they are cultured under normal laboratory conditions. For example, gonococci adapted to growth in chambers implanted subcutaneously into guinea-pigs were found to be resistant to human serum but loss of this phenotypically acquired resistance took place after a few generations in vitro in culture medium and in fluid taken from guinea-pig chambers (Rittenberg et al., 1977). Similarly, McElree, Pitcher and Arnwine (1966) found that a serum-sensitive strain of Escherichia coli acquired phenotypic resistance to serum after multiplication in rat mononuclear cells; resistance was rapidly lost during subculture on artificial media. Antigens associated with prevention of phagocytosis of Yersinia pestis and with resistance of Brucella abortus to the intracellular bactericidins of bovine phagocytes were produced by bacteria grown in vivo but not in vitro (Smith, 1977).

These observations are probably related to bacterial surface changes due to multiplication in a growth-limiting environment. In a recent study (Taylor, 1978 ) the sensitivity of chemostat-grown strains of $E$. coli to normal human serum was investigated. There was a tendency for slow-growing cells to be more resistant than rapidly-growing cells and for magnesium ion-limited (Mg-lim) cultures to be more sensitive than carbon-limited (C-lim) cultures.

The basis of serum resistance in gram-negative bacteria has not been defined with any certainty. It has been suggested that resistant strains contain larger amounts of lipopolysaccharide in the cell envelope than sensitive strains (Wardlaw, 1963) and also that long or numerous lipopolysaccharide $\mathrm{O}$ side chains are responsible for resistance (Feingold, 1969). Glynn and Howard (1970) suggested that serum-resistant strains of $E$. coli produce larger amounts of acidic exopolysaccharide $\mathrm{K}$ antigen with higher erythrocyte agglutinationinhibition activity than sensitive strains. More recently Taylor and Parton (1977) found that greater amounts of a 46k envelope protein could be extracted from a serum-resistant mutant of $E$. coli than from the sensitive parent strain. In the present study cell-envelope components of $E$. coli strains grown under various steady-state conditions have been examined in an attempt to explain the observed changes in serum reactivity.

\section{MATERIALS AND METHODS}

Bacteria and growth conditions. E. coli strains LP1674 (serotype O7:K1), LP729 (O9) and LP1395 (O18) were isolated from patients with urinary-tract infections. They were grown in the nutrient-limited media of Evans, Herbert and Tempest (1970) in a 1-L chemostat (L.H. Engineering Co., Stoke Poges, Bucks) at constant $p \mathrm{H} \mathrm{(6.5)}$ and temperature $\left(37^{\circ} \mathrm{C}\right)$ as described previously (Taylor and Sleytr, 1977). Strains were grown over a range of dilution rates (D) under conditions of C-lim and $\mathrm{Mg}$-lim (table 1). The response of bacteria grown in nutrient-limited culture to normal human serum is also shown in table I. Serum-sensitivity tests were performed on portions of bacterial suspension removed from the culture vessel during collection of cells for envelope analysis. For serum-sensitivity determination, bacterial samples were immediately diluted in Tris- $\mathrm{HCl} p \mathrm{H} 8.4$ to give a cell concentration of $1.0-2.0 \times 10^{6} / \mathrm{ml} ; 0.5 \mathrm{ml}$ of this 
suspension was added to $1.5 \mathrm{ml}$ of human serum and viable counts were obtained by the pour-plate technique at the beginning of each test and after incubation for 1,2 and $3 \mathrm{~h}$ at $37^{\circ} \mathrm{C}$ (Taylor, 1978).

Preparation of lipopolysaccharides and acidic polysaccharides. Cells from $1 \mathrm{~L}$ of chemostat culture were washed once with water and lyophilised, and the dry weight was determined (usually $2-5 \mathrm{~g} / \mathrm{L})$. The cell mass was then extracted twice with $45^{\circ} \%(\mathrm{w} / \mathrm{v})$ phenol at $68^{\circ} \mathrm{C}$ (Westphal and Jann, 1965) and the water layers pooled and dialysed against running tap water for $24-72 \mathrm{~h}$. The extracts were then subjected to fractional cetrimide precipitation according to procedure III of Westphal and Jann (1965). Fractions representing lipopolysaccharides and acidic polysaccharides were dried to constant weight.

Sugar determinations. For the determination of neutral sugars, $2 \mathrm{mg}$ of lipopolysaccharide was hydrolysed $\left(100^{\circ} \mathrm{C}, 48 \mathrm{~h}\right)$ in sealed tubes containing $2 \mathrm{ml} \mathrm{of} 0.1 \mathrm{~N} \mathrm{HCl}$, and $0.1 \mathrm{ml} \mathrm{of} 0.005 \mathrm{M}$ xylose was then added as an internal standard (Schmidt, Fromme and Mayer, 1970). The hydrolysate was then neutralised with Amberlite IRA $410\left(\mathrm{HCO}_{3}{ }^{-}\right)$. Heptose-linked phosphate residues were removed by treatment with calf-intestine alkaline phosphatase (Boehringer Mannheim $\mathrm{GmbH}$, West Germany) and aldoses were converted to the corresponding alditol acetates according to the procedure described by Holme et al. (1968). Alditol acetates were dissolved in $0.2 \mathrm{ml}$ of chloroform and $1-\mathrm{ml}$ samples were injected into a Hewlett Packard Series 5840A gas chromatograph fitted with $2.7 \times 2-\mathrm{mm}$ glass columns containing $3 \%$ ECNSS-M on 100 to 120-mesh Gas-Chrom Q (Applied Science Laboratories, State College, Pennsylvania, USA). Separations were obtained isothermally $\left(180^{\circ} \mathrm{C}\right)$ with a nitrogen carrier-gas flow of $50 \mathrm{ml} / \mathrm{min}$ and peaks were identified by comparison with authentic alditol acetates.

3-Deoxy-D-manno-octulosonic acid (KDO) was determined by the method of Warren (1959). Hexuronic acids were determined by the method of Dische (1947); neuraminic acid was estimated by the modified Ehrlich procedure (Barry, Abbott and Tsai, 1962).

Passive haemagglutination. Antisera against four complete lipopolysaccharide core (R) antigens were prepared in rabbits by the method of Schlecht and Westphal (1967) with E. coli strains F470 (complete R1 core), F576 (R2), F653 (R3) and F2516 (R4). These strains were obtained from Dr G. Schmidt, Max-Planck-Institut für Immunbiologie, Freiburg, West Germany. Lipopolysaccharide $(1 \mathrm{mg})$ was treated with $0.02 \mathrm{~N} \mathrm{NaOH}$ for $18 \mathrm{~h}$ at $37^{\circ} \mathrm{C}$ and, after neutralisation, used in passive haemagglutination tests according to Schmidt $\mathrm{et}$ al. (1970).

Erythrocyte-agglutination inhibition. The ability of acidic polysaccharides to inhibit the agglutination of sheep erythrocytes by rabbit anti-sheep erythrocyte serum was determined by the technique of Glynn and Howard (1970).

Envelope preparations. Dried cells were resuspended in saline and, after freezing, were broken by three passages through an LK B X-press. Envelopes were then prepared as previously described (Taylor and Parton, 1977).

Electrophoresis. Slab-gel electrophoresis with a discontinuous SDS buffer system was based on the method of Laemmli (1970) as modified by Ames (1974). Separating and stacking gels contained $11 \%(\mathrm{w} / \mathrm{v})$ and $5 \%(\mathrm{w} / \mathrm{v})$ of acrylamide respectively. Protein bands were stained with Coomassie Brilliant Blue R250 (BDH Ltd, Poole, Dorset). A full description of the electrophoretic procedures is given by Parton (1975). For molecular-weight determinations, Combithek (Boehringer Mannheim GmbH) and MW-SDS-70 (Sigma Chemical Company) marker protein kits were used.

\section{RESULTS}

All strains were examined under conditions of $\mathrm{C}$-lim and $\mathrm{Mg}$-lim over dilution rates ranging from $0 \cdot 1 \mathrm{~h}^{-1}$ to values approaching the washout point.

\section{Strain LP1674}

In batch culture, $E$. coli strain LP1674 produces the acidic polysaccharide $\mathrm{K} 1$ antigen which is a homopolymer of $\mathrm{N}$-acetylneuraminic acid. When 
grown under C-lim, this strain was serum resistant (table I) and produced the $\mathrm{K} 1$ antigen in amounts ranging from 2.5 to $5.2 \%$ dry weight of the total cell mass depending on the value of $\mathrm{D}$; the maximum amount of polymer could be extracted from the cell mass at $D=0.4 \mathrm{~h}^{-1}$ (table II). The haemagglutinationinhibiting capacity of the polymers did not vary significantly over the range of D values employed (table II). Acidic polysaccharides extracted from strain LP1674, and the two other strains examined in this study, were free from contaminating ribonucleic acid and produced a single precipitin line in Ouchterlony gel-diffusion tests with antisera raised against the appropriate live cell suspension.

The strain became serum sensitive when grown under Mg-lim (table I). Cells grown at low $D$ values were killed by serum but only after a delay of $1 \mathrm{~h}$; as $\mathrm{D}$ increased, the delayed killing effect became less marked. Acidic polysac-

\section{TABLE I}

Response to normal human serum of urinary strains of Escherichia coli grown under various conditions in the chemostat

\begin{tabular}{|c|c|c|c|c|c|}
\hline \multirow[b]{2}{*}{ Strain no. } & \multirow{2}{*}{$\begin{array}{l}\text { Nutrient } \\
\text { limitation }\end{array}$} & \multirow{2}{*}{$\begin{array}{c}\text { Dilution } \\
\text { rate } \\
\left(\mathrm{h}^{-1}\right)\end{array}$} & \multicolumn{3}{|c|}{$\begin{array}{l}\text { Percentage } \\
\text { survival *at }\end{array}$} \\
\hline & & & $1 \mathrm{~h}$ & $2 \mathrm{~h}$ & $3 \mathrm{~h}$ \\
\hline LP1674 & Magnesium & $\begin{array}{l}0.1 \\
0.2 \\
0.4 \\
0.6 \\
0.8 \\
0.1 \\
0.2 \\
0.4 \\
0.6 \\
0.8\end{array}$ & $\begin{array}{r}98 \\
164 \\
172 \\
120 \\
182 \\
49 \\
12 \\
10 \\
3 \\
4\end{array}$ & $\begin{array}{l}197 \\
490 \\
727 \\
536 \\
803 \\
<1 \\
<1 \\
<1 \\
<1 \\
<1\end{array}$ & $\begin{array}{r}717 \\
953 \\
1127 \\
793 \\
515 \\
<1 \\
<1 \\
<1 \\
<1 \\
<1\end{array}$ \\
\hline LP729 & Magnesium & $\begin{array}{l}0.1 \\
0.2 \\
0.4 \\
0.6 \\
0.8 \\
1.0 \\
0.1 \\
0.2 \\
0.4 \\
0.6\end{array}$ & $\begin{array}{r}118 \\
132 \\
56 \\
6 \\
7 \\
19 \\
10 \\
9 \\
1 \\
<1\end{array}$ & $\begin{array}{r}<1 \\
<1 \\
<1 \\
<1 \\
<1 \\
\\
<1 \\
<1 \\
<1 \\
<1 \\
<1\end{array}$ & $\begin{array}{l}<1 \\
<1 \\
<1 \\
<1 \\
<1 \\
<1 \\
<1 \\
<1 \\
<1 \\
<1\end{array}$ \\
\hline LP1395 & Magnesium & $\begin{array}{l}0.1 \\
0.2 \\
0.4 \\
0.6 \\
0.8 \\
0.1 \\
0.2 \\
0.4\end{array}$ & $\begin{array}{r}116 \\
137 \\
169 \\
277 \\
37 \\
162 \\
170 \\
159\end{array}$ & $\begin{array}{r}297 \\
336 \\
510 \\
665 \\
6 \\
711 \\
858 \\
81\end{array}$ & $\begin{array}{r}705 \\
559 \\
775 \\
544 \\
6 \\
1118 \\
1698 \\
10\end{array}$ \\
\hline
\end{tabular}

* Percentage survival in normal human serum of chemostat-grown bacteria. Data from Taylor (1978). Each value represents the mean of at least three determinations. 


\section{VIRUS ASSOCIATED WITH GASTROENTERITIS}
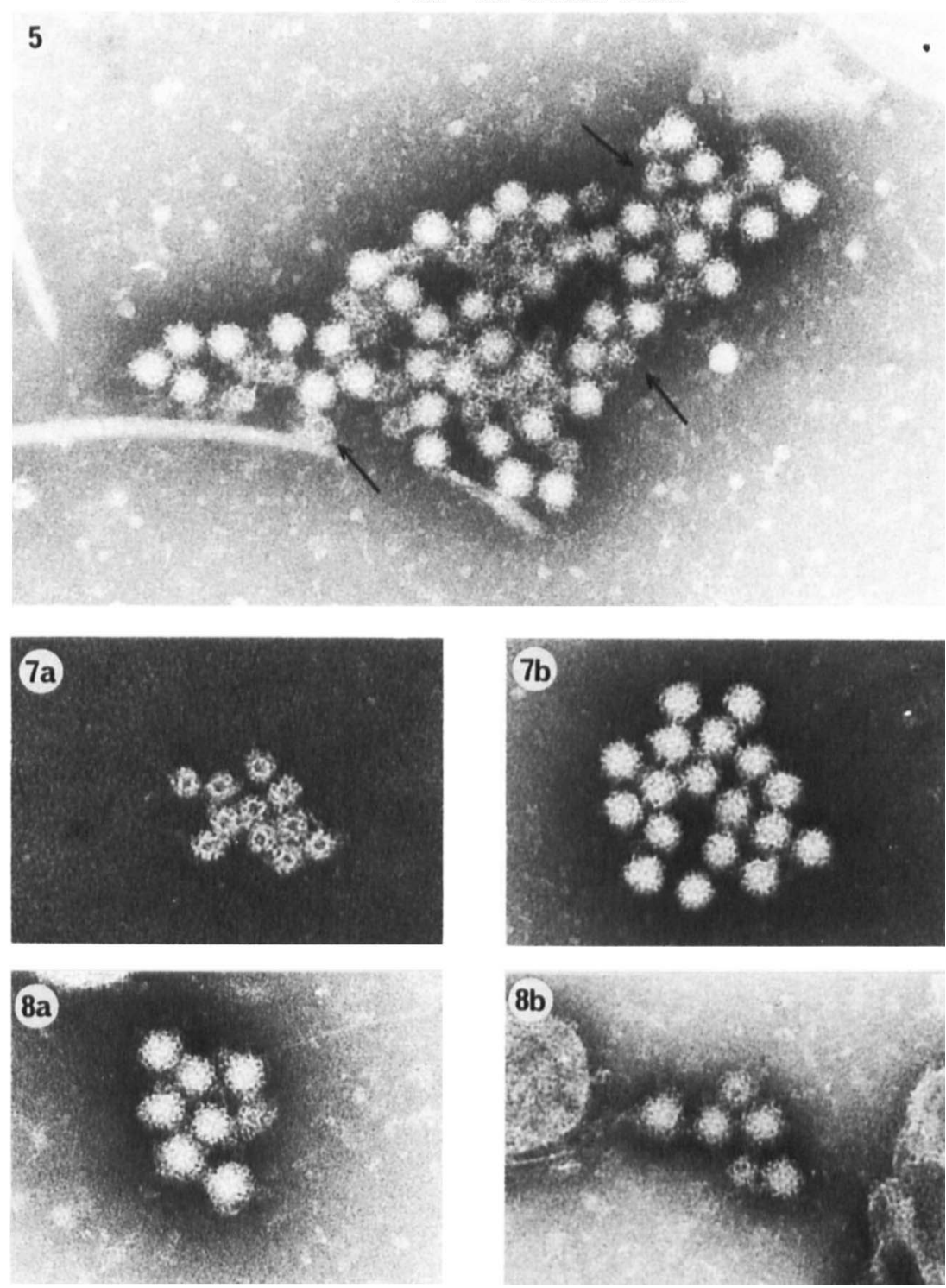

FIG. 5.-Particlesfrom patient no. 20 in outbreak no. 5 agglutinated by a convalescent serum from the same incident. Small "empty" particles measuring $15-20 \mathrm{~nm}$ in diameter are observed in a complex mainly composed of the 35-40-nm particles (indicated by arrows). PTA. x 126750.

FIGS. 7a and b. -The 15-20-nm "empty" particles (7a) and the 35-40-nm particles (7b) derived from, respectively. fractions 4 and 15 in $\mathrm{CsCl}$ density gradient centrifugation (see fig. 6). They were agglutinated by a convalescent serum from patient no. 20 in outbreak no. 5. PTA. $\times 126750$.

FIGS. $8 \mathrm{a}$ and b. -An aggregate containing the 35-40-nm particles and the 15-20-nm "empty" particles. The two types of particles were successively added to a convalescent serum (patient no. 20) from outbreak no. 5. PTA. $\times 126750$. 
charide could not be extracted from $\mathrm{Mg}$-lim cells over the range of $\mathrm{D}$ values employed (table II).

Comparable amounts of lipopolysaccharide could be extracted from C-lim and from Mg-lim cultures of strain LP1674 (table III). In E. coli strains of serotype 07 , rhamnose is a component of the lipopolysaccharide $\mathrm{O}$ side chain and L-glycero-D-mannoheptose is confined to the core region. Although C-lim cells of strain LP1674 were serum resistant and Mg-lim cells serum sensitive, there were no obvious differences between the rhamnose:heptose ratios of lipopolysaccharides extracted from this strain. Rapidly growing $\left(\mathrm{D}=0.8 \mathrm{~h}^{-1}\right)$ cells, however, appeared to have slightly lower rhamnose: heptose ratios than more slowly growing cells (table III). Red cells coated with lipopolysaccharide from C-lim and Mg-lim cultures of strain LP1674 agglutinated in anti-F470 antiserum (table III) but failed to agglutinate in antisera raised against strains F576, F653 and F2516, indicating that strain LP1674 produced the $\mathrm{R} 1$ core type under all growth conditions examined. Lipopolysaccharide preparations from $\mathrm{Mg}$-lim cells tended, however, to give slightly higher titres.

TABLE II

Analysis of acidic polysaccharide obtained by cetrimide precipitation from phenol-water extracts of chemostat-grown cultures of Escherichia coli

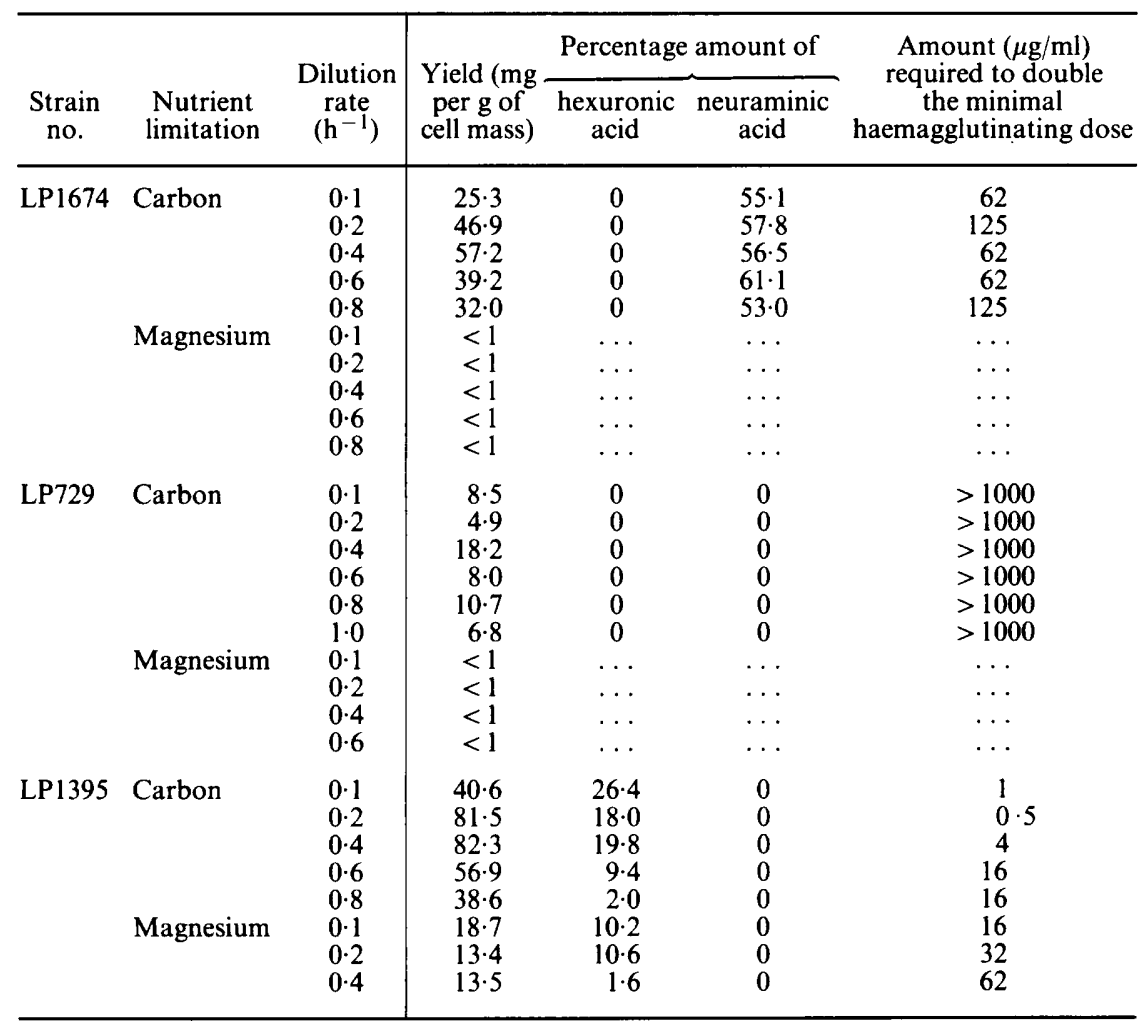


TABLE III

Analysis of lipopolysaccharides extracted with phenol-water from chemostat-grown cells of Escherichia coli

\begin{tabular}{|c|c|c|c|c|c|c|c|c|c|c|c|c|}
\hline \multirow{3}{*}{$\begin{array}{c}\text { Strain } \\
\text { no. }\end{array}$} & \multirow{3}{*}{$\begin{array}{c}\text { Nutrient } \\
\text { limitation }\end{array}$} & \multirow{3}{*}{$\begin{array}{c}\text { Dilution } \\
\text { rate } \\
\left(\mathrm{h}^{-1}\right)\end{array}$} & \multirow{3}{*}{$\begin{array}{l}\text { Yield (mg/ } \\
\text { g of } \\
\text { cell mass) }\end{array}$} & \multirow{2}{*}{\multicolumn{2}{|c|}{$\begin{array}{l}\text { PHA titre } \\
\text { of antiserum* } \\
\text { raised against } \\
\text { strain no. }\end{array}$}} & \multirow[b]{3}{*}{ Rhamnose } & \multirow[b]{3}{*}{ Mannose } & \multicolumn{2}{|c|}{ Molar ratio of } & \multirow{3}{*}{$\begin{array}{l}\text { D-glycero- } \\
\text { D-manno- } \\
\text { heptose }\end{array}$} & \multirow{3}{*}{$\begin{array}{l}\text { L-glycero- } \\
\text { D-manno- } \\
\text { heptose }\end{array}$} & \multirow{3}{*}{$\underset{(\mu \mathrm{g} / \mathrm{mg} \text { of LPS })}{\mathrm{KDO}}$} \\
\hline & & & & & & & & & & & & \\
\hline & & & & F470 & F576 & & & Galactose & Glucose & & & \\
\hline LP1674 & Magnesium & $\begin{array}{l}0 \cdot 1 \\
0 \cdot 2 \\
0 \cdot 4 \\
0 \cdot 6 \\
0 \cdot 8 \\
0 \cdot 1 \\
0 \cdot 2 \\
0 \cdot 4 \\
0 \cdot 6 \\
0 \cdot 8\end{array}$ & $\begin{array}{l}68 \cdot 6 \\
71 \cdot 2 \\
77 \cdot 8 \\
86 \cdot 4 \\
70 \cdot 9 \\
56 \cdot 7 \\
55 \cdot 5 \\
66 \cdot 3 \\
59 \cdot 2 \\
67 \cdot 6\end{array}$ & $\begin{array}{r}320 \\
160 \\
640 \\
320 \\
320 \\
640 \\
1280 \\
640 \\
640 \\
640\end{array}$ & $\begin{array}{l}<20 \\
<20 \\
<20 \\
<20 \\
<20 \\
<20 \\
<20 \\
<20 \\
<20 \\
<20\end{array}$ & $\begin{array}{l}0.60 \\
0.47 \\
0.56 \\
1.19 \\
0.34 \\
0.61 \\
0.81 \\
0.61 \\
0.89 \\
0.46\end{array}$ & $\begin{array}{l}3 \cdot 80 \\
2 \cdot 66 \\
3 \cdot 29 \\
1 \cdot 47 \\
2 \cdot 04 \\
2 \cdot 28 \\
2 \cdot 29 \\
2 \cdot 30 \\
2 \cdot 54 \\
2 \cdot 20\end{array}$ & $\begin{array}{l}6 \cdot 15 \\
5 \cdot 36 \\
6 \cdot 59 \\
4 \cdot 57 \\
5 \cdot 77 \\
4 \cdot 42 \\
4 \cdot 36 \\
4 \cdot 75 \\
4 \cdot 55 \\
4 \cdot 70\end{array}$ & $\begin{array}{l}0.71 \\
0.97 \\
0.81 \\
0.34 \\
0.45 \\
0.83 \\
0.93 \\
0.77 \\
0.71 \\
0.73\end{array}$ & $\begin{array}{l}0 \\
0 \\
0 \\
0 \\
0 \\
0 \\
0 \\
0 \\
0 \\
0\end{array}$ & $\begin{array}{l}1.00 \\
1.00 \\
1.00 \\
1.00 \\
1.00 \\
1.00 \\
1.00 \\
1.00 \\
1.00 \\
1.00\end{array}$ & $\begin{array}{r}85 \\
97 \\
89 \\
106 \\
96 \\
96 \\
91 \\
102 \\
100 \\
82\end{array}$ \\
\hline LP729 & Magnesium & $\begin{array}{l}0 \cdot 1 \\
0 \cdot 2 \\
0 \cdot 4 \\
0 \cdot 6 \\
0 \cdot 8 \\
1 \cdot 0 \\
0 \cdot 1 \\
0 \cdot 2 \\
0 \cdot 4 \\
0 \cdot 6\end{array}$ & $\begin{array}{r}106.0 \\
111.5 \\
92.9 \\
84.4 \\
64.2 \\
82.7 \\
98.7 \\
72.3 \\
69.2 \\
31.7\end{array}$ & $\begin{array}{l}<20 \\
<20 \\
<20 \\
<20 \\
<20 \\
<20 \\
<20 \\
<20 \\
<20 \\
\ldots\end{array}$ & $\begin{array}{r}320 \\
640 \\
1280 \\
640 \\
1280 \\
1280 \\
1280 \\
640 \\
2560 \\
\ldots\end{array}$ & $\begin{array}{l}0 \\
0 \\
0 \\
0 \\
0 \\
0 \\
0 \\
0 \\
0 \\
0\end{array}$ & $\begin{array}{r}16.42 \\
18.90 \\
16.33 \\
10.36 \\
6.67 \\
10.30 \\
9.54 \\
7.92 \\
5.54 \\
6.59\end{array}$ & $\begin{array}{l}0.67 \\
0.77 \\
0.87 \\
0.75 \\
0.60 \\
0.93 \\
0.66 \\
0.92 \\
0.66 \\
1.12\end{array}$ & $\begin{array}{l}0.77 \\
1.06 \\
1.28 \\
1.22 \\
0.85 \\
1.26 \\
0.93 \\
1.23 \\
0.61 \\
1.44\end{array}$ & $\begin{array}{l}0.22 \\
0.24 \\
0.84 \\
0.62 \\
0 \cdot 48 \\
0.42 \\
0.34 \\
0.29 \\
0.22 \\
0 \cdot 17\end{array}$ & $\begin{array}{l}1.00 \\
1.00 \\
1.00 \\
1.00 \\
1.00 \\
1.00 \\
1.00 \\
1.00 \\
1.00 \\
1.00\end{array}$ & $\begin{array}{r}98 \\
100 \\
121 \\
138 \\
175 \\
143 \\
114 \\
156 \\
178 \\
199\end{array}$ \\
\hline LP1395 & Magnesium & $\begin{array}{l}0.1 \\
0.2 \\
0.4 \\
0.6 \\
0.8 \\
0 \cdot 1 \\
0.2 \\
0.4\end{array}$ & $\begin{array}{r}97 \cdot 4 \\
76 \cdot 7 \\
72 \cdot 0 \\
74 \cdot 7 \\
85 \cdot 1 \\
108.4 \\
93 \cdot 8 \\
102 \cdot 2\end{array}$ & $\begin{array}{r}160 \\
320 \\
320 \\
320 \\
640 \\
80 \\
80 \\
160\end{array}$ & $\begin{array}{l}<20 \\
<20 \\
<20 \\
<20 \\
<20 \\
<20 \\
<20 \\
<20\end{array}$ & $\begin{array}{l}0 \cdot 75 \\
0 \cdot 19 \\
0 \cdot 48 \\
0 \cdot 38 \\
0 \cdot 13 \\
0 \cdot 70 \\
0 \cdot 11\end{array}$ & $\begin{array}{l}0 \\
0 \\
0 \\
0 \\
0 \\
. \\
0 \\
0\end{array}$ & $\begin{array}{l}5 \cdot 76 \\
6.57 \\
4.66 \\
4.94 \\
3.61 \\
7.9 \\
4.90 \\
4.41\end{array}$ & $\begin{array}{l}2 \cdot 81 \\
2 \cdot 56 \\
3 \cdot 31 \\
3.03 \\
1.13 \\
\ldots .68 \\
3.68 \\
1.20\end{array}$ & $\begin{array}{l}0 \\
0 \\
0 \\
0 \\
0 \\
. \cdots \\
0 \\
0\end{array}$ & $\begin{array}{l}1.00 \\
1.00 \\
1.00 \\
1.00 \\
1.00 \\
1 . . \\
1.00 \\
1.00\end{array}$ & $\begin{array}{l}78 \\
82 \\
85 \\
82 \\
65 \\
80 \\
81\end{array}$ \\
\hline
\end{tabular}

PHA $=$ passive haemagglutination, $K D O=3$-deoxy-D-manno octulosonic acid, $L P S=$ lipopolysaccharide .

* Anti-F470 and anti-F576 antisera were produced from the E. coli R1 and R2 complete lipopolysaccharide core reference strains of Schmidt et al. (1970). The titre against lipopolysaccharide from the homologous strains was 5120 in both cases. 
The envelope protein profiles of C-lim and Mg-lim LP1674 cells are shown in fig. 1. Differences between C-lim and Mg-lim envelopes were apparent. In particular, C-lim envelopes contained a 46k polypeptide band that decreased in amount as $\mathrm{D}$ was increased. This band was virtually absent from $\mathrm{Mg}$-lim envelope profiles. In Mg-lim cells, a $42 \mathrm{k}$ polypeptide band increased in amount as D was increased.

\section{Strain LP729}

Under C-lim, strain LP729 was sensitive to serum but only after a lag of $1 \mathrm{~h}$; as $\mathrm{D}$ was increased there was a tendency for this lag to become less pronounced. Mg-lim cells were more serum sensitive without lag in killing at D values of 0.4 and $0.6 \mathrm{~h}^{-1}$ (table I).

As previously found with batch-grown cells (Taylor, 1976), C-lim cultures of $E$. coli strain LP729 produced small amounts of K antigen containing neither uronic acids nor neuraminic acid as the negatively charged component and did not possess haemagglutination-inhibiting activity (table II). No material could be obtained by cetrimide precipitation from phenol-water extracts of Mg-lim cells of strain LP729.

More lipopolysaccharide could be extracted from C-lim than from $\mathrm{Mg}$-lim cells grown at the same $\mathrm{D}$ value and yields tended to decrease as $\mathrm{D}$ increased (table III) and as serum sensitivity increased (table I). The $\mathrm{O}$ side chain of lipopolysaccharide from serotype $\mathrm{O} 9$ strains is a mannan (Reske and Jann, 1972). The lipopolysaccharide mannose: L-glycero-D-mannoheptose ratio of $\mathrm{C}$-lim cells tended to decrease as $\mathrm{D}$ was increased and this decrease in the $\mathrm{O}$ side-chain-sugar: core-sugar ratio and the amount of extractable lipopolysaccharide paralleled the decrease in the degree of delayed serum killing observed (tables I and III). Lipopolysaccharides from Mg-lim cells had a lower mannose: L-glycero-D-mannoheptose ratio than C-lim cells and this also tended to decrease with increasing D. D-glycero-D-mannoheptose was found in all lipopolysaccharide preparations from this strain. Strain LP729 produced the R2 core under all growth conditions used in this study (table III).

Protein profiles indicated that envelopes from C-lim cells of strain LP729 contained a 46k polypeptide component which was particularly prominent in $\mathrm{C}-\lim \mathrm{D}=0 \cdot 4$ and $0 \cdot 6-\mathrm{h}^{-1}$ preparations (fig. 2). In C-lim profiles, the intensity of the $37 \mathrm{k}$ band decreased with increasing $\mathrm{D}$, whereas with $\mathrm{Mg}$-lim the amount of this polypeptide increased with increasing $\mathrm{D}$. In C-lim and in Mg-lim cells, a $42 \mathrm{k}$ component became more prominent at high $\mathrm{D}$ values.

\section{Strain LP1395}

Under C-lim and under Mg-lim, strain LP1395 was serum resistant except when $\mu$ was close to $\mu$ max. (table I). Large amounts of acidic polysaccharide could be extracted from $\mathrm{C}$-lim cells but much less was obtained from $\mathrm{Mg}$-lim cells (table II). Maximum yields were obtained from C-lim cells at $D=0 \cdot 2$ and $0.4 \mathrm{~h}^{-1}$. As previously determined (Taylor, 1976), cetrimide-precipitated 
material from phenol-water extracts of this strain contained hexuronic acid. The amount of uronic acid in the polymer, however, varied according to D. The material, which formed a single sharp precipitin line in Ouchterlony gel-diffusion tests against anti-LP1395 antiserum, also contained small amounts of KDO and reacted with anti-F470 antiserum in passive haemagglutination tests, suggesting that this polymer might be an acidic lipopolysaccharide. The acidic polymers from strain LP1395 possessed considerable haemagglutination-inhibiting activity; the most active were those from slowly growing C-lim cultures (table II).

Large amounts of lipopolysaccharide containing the $\mathrm{R} 1$ core could be extracted from $\mathrm{C}$-lim and from $\mathrm{Mg}$-lim cells (table III). The $\mathrm{O}$ side-chain sugar:core-sugar (rhamnose:heptose) ratio was lowest when C-lim and $\mathrm{Mg}$-lim cells were growing at rates close to $\mu$ max.

As with strain LP729, envelopes from C-lim cells of strain LP1395 grown at $D$ values of 0.4 and $0.6 \mathrm{~h}^{-1}$ contained a prominent 46k component which was much less prominent in other $\mathrm{C}$-lim and in $\mathrm{Mg}$-lim preparations (fig. 3). In addition, in C-lim and in Mg-lim cells, the amount of the 42k component again appeared to increase as D increased.

\section{Discussion}

It is clear that the dilution rate and the nature of the growth-limiting nutrient had a profound effect on the surface components of the $E$. coli strains examined in this study. Under $C$-lim, all three strains produced polymers that could be extracted from the cell mass with phenol-water and purified by fractional precipitation with cetrimide. In two cases, production of these acidic polysaccharides ceased when the cells were grown under Mg-lim, and in the third case the amount of the polymer that could be extracted was greatly reduced. Strain LP1674 produced the K1 antigen under C-lim but not under $\mathrm{Mg}$-lim. This antigen has been associated with the ability of E. coli strains to produce neonatal meningitis (Robbins et al., 1974; Sarff et al., 1975), an infection with a high case-fatality rate, and strains possessing the $\mathrm{K} 1$ capsular polysaccharide were found to be more virulent in rat-challenge experiments than strains lacking this antigen (Bortolussi, Ferrieri and Wannamaker, 1978). It is, therefore, of considerable interest that changing the nature of the limiting nutrient in steady-state cultures of strain LP1674 can result in loss of ability to synthesise the polymer.

Lipopolysaccharides from strains LP1674 and LP1395 were not greatly affected by changes in the growth environment, although the $\mathrm{O}$ side-chain sugar : core-sugar ratio of strain LP1395 lipopolysaccharide tended to be lower at high $D$ values, when cells became serum sensitive. However, more lipopolysaccharide $\mathrm{O}$ side-chain material was associated with $\mathrm{C}$-lim than with $\mathrm{Mg}$-lim cells of strain LP729 at any given D value, and with both types of nutrient limitation, increases in $\mathrm{D}$ resulted in decreases in the amount of the $\mathrm{O}$ sidechain sugar mannose.

With all three strains, envelopes from C-lim cells grown at particular D 


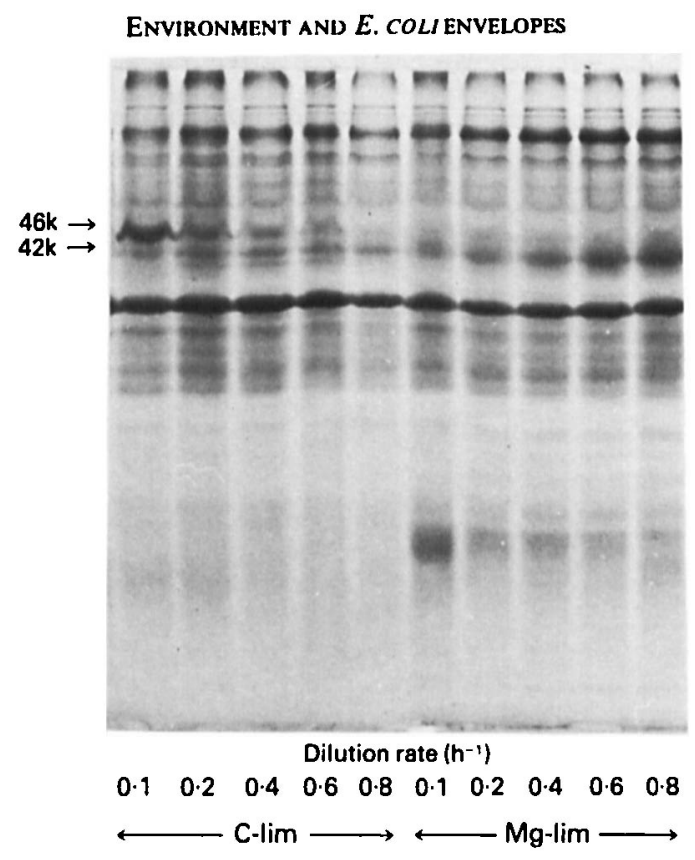

FIG. 1.-Slab-gel electrophoresis showing envelope-protein profiles of carbon-limited (C-lim) and magnesimlimited (Mg-lim) cells of Escherichia coli strain LP1674.

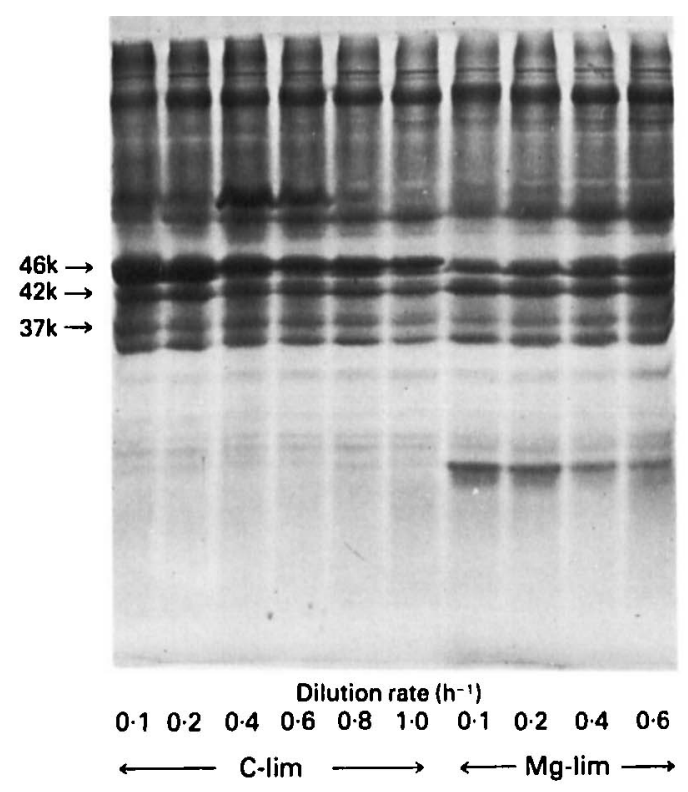

FIG. 2.-Envelope-protein profiles of C-lim and $\mathrm{Mg}$-lim cells of E. coli strain LP729.

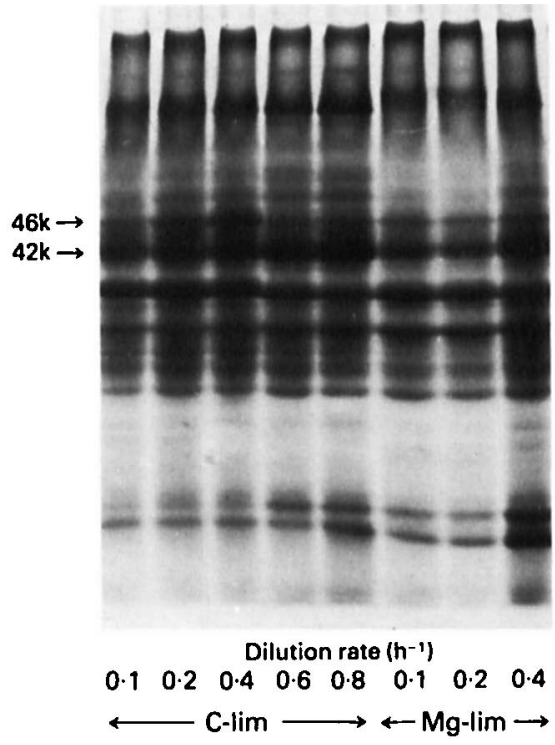

FIG. 3.-Envelope-protein profiles of C-lim and $\mathrm{Mg}$-lim cells of $E$. coli strain LP1395.

[facing page 16 
values contained more of a $46 \mathrm{k}$ polypeptide component than envelopes from other C-lim cells and from all Mg-lim cells. This polypeptide was previously shown (Taylor and Parton, 1977) to be present in a more readily extractable form in E. coli strain I7, a serum-resistant mutant obtained from strain LP729, and it was suggested that this envelope component was in some way partly responsible for the serum resistance of strain 17 . The present observations tend to support the validity of that suggestion, because strains LP729 and LP1674 were more sensitive to serum when growing under Mg-lim (table I). However, the amount of the 46k component in C-lim envelopes was not directly related to serum resistance; this suggests that additional factors must be considered.

It is highly unlikely that the small amounts of acidic polysaccharide associated with C-lim cells of strain LP729 would be able significantly to influence serum sensitivity, and batch cultures of strain LP729 and the serum-resistant mutant 17 contained comparable amounts of this polymer (Taylor, 1975). However, as Mg-lim cells of strain LP1674 were serum sensitive and did not produce acidic polysaccharide, the $\mathrm{K} 1$ antigen probably contributed to the serum resistance of C-lim cells of this strain. There appears to be no simple relationship between serum resistance and the carriage of $\mathrm{K} 1$ (Björkstén $e t$ al., 1976) and other K antigens (Taylor, 1976; Olling, 1977; Taylor and Hughes, 1978; Taylor, Hughes and Robinson, 1979) and more investigations will be necessary to define the precise contribution of these polysaccharides to the determination of resistance.

Previous studies have indicated that a full complement of lipopolysaccharide $\mathrm{O}$ side chains is responsible for the delay in serum killing that is a characteristic of many smooth serum-sensitive strains of $E$. coli (Taylor, 1975; Taylor, Hughes and Robinson, 1979). With strain LP729, however, the delayed killing became less pronounced as $\mathrm{D}$ was increased and this coincided with a progressive reduction in the yield of lipopolysaccharide extracted and in the $\mathrm{O}$ side-chain sugar:core-sugar ratio of the lipopolysaccharide.

With strain LP1395 the amount of uronic acid-containing polysaccharide did not appear to account for the serum sensitivity of rapidly growing cells (table II). Reduced amounts of lipopolysaccharide $\mathrm{O}$ side-chain sugar and the 46k envelope polypeptide were found in rapidly growing cells of strain LP1395 but more study will be necessary to determine whether these relatively minor changes are responsible for the observed increase in serum sensitivity.

It appears that no single factor, such as the amount or composition of the LPS, $\mathrm{K}$ antigen or envelope protein, can readily explain the differences in serum sensitivity observed with the three strains of $E$. coli grown under the various conditions used in this study. It seems likely that in each strain a different combination of these factors contributes to serum resistance or that some other, as yet undefined, factor is involved.

P. W. T. thanks the Medical Research Council for a project grant. We would like to thank Dr Frank Unger for his interest in this work. 


\section{REFERENCES}

AMEs, G. F. 1974. Resolution of bacterial proteins by polyacrylamide gel electrophoresis on slabs. Membrane, soluble and periplasmic fractions. J. biol. Chem., 249, 634 .

Barry, G. T., AbBotT, V. AND Tsai, T. 1962. Relationship of colominic acid (poly N-acetylneuraminic acid) to bacteria which contain neuraminic acid. J. gen. Microbiol., 29, 335.

BJöRKstén, B., Bortolussi, R., GotheFoRs, L. AND QUIE, P.G. 1976. Interaction of E. coli strains with human serum: lack of relationship to K1 antigen. J. Pediat., 89, 892.

Bortolussi, R., Ferrieri, P. AND Wannamaker, L.W. 1978. Dynamics of Escherichia coli infection and meningitis in infant rats. Infect. Immun., 22, 480.

DisCHE, Z. 1947. A new specific color reaction of hexuronic acids. J. biol. Chem., 167, 189.

Evans, C. G. T., Herbert, D. and Tempest, D. W. 1970. The continuous cultivation of micro-organisms. 2. Construction of a chemostat. In Methods in microbiology, vol. 2, edited by J. R. Norris and D. W. Ribbons, Academic Press, London, p. 277.

FEINGOLD, D. S. 1969. The serum bactericidal reaction, IV. Phenotypic conversion of Escherichia coli from serum-resistance to serum-sensitivity by diphenylamine. J. infect. Dis., 120, 437.

GlynN, A.A. AND Howard, C.J. 1970. The sensitivity to complement of strains of Escherichia coli related to their $\mathrm{K}$ antigens. Immunology, 18, 331 .

Holme, T., Lindberg, A. A., GaregG, P. J. AND ONN, T. 1968. Chemical composition of cell wall polysaccharide of rough mutants of Salmonella typhimurium. J.gen. Microbiol., 52, 45.

LAEMMLI, U. K. 1970. Cleavage of structural proteins during the assembly of the head of bacteriophage T4. Nature, Lond., 227, 680.

MCElree, H., PITChER, J. AND ARNwINE, J. 1966. Transiently acquired serum resistance by cell-grown Escherichia coli. J. infect. Dis., 116, 231.

OLLING, S. 1977. Sensitivity of gram-negative bacilli to the serum bactericidal activity: a marker of the host-parasite relationship in acute and persisting infections. Scand. J. infect. Dis., suppl., 10, 1.

PARTON, R. 1975. Envelope proteins in Salmonella minnesota mutants. J. gen. Microbiol., 89, 113.

ReSKE, K. AND JANN, K. 1972. The O8 antigen of Escherichia coli. Structure of the polysaccharide chain. Eur. J. Biochem., 31, 320.

Rittenberg, S. C., Penn, C. W., Parsons, N. J., Veale, D. R. and Smith, H. 1977. Phenotype changes in the resistance of Neisseria gonorrhoeae to killing by normal human serum. $J$. gen. Microbiol., 103, 69.

Robbins, J.B., McCracken, G. H. JR., Gotschlich, E. C., Ørskov, F., Ørskov, I. and HANSON, L. A. 1974. Escherichia coli K1 capsular polysaccharide associated with neonatal meningitis. N. Engl. J. Med., 290, 1216.

SarfF, L.D., McCracken, G. H. JR., Schiffer, M. S., Glode, M. P., Robbins, J. B., ØrSkov, I. AND ØRSKov, F. 1975. Epidemiology of Escherichia coli $\mathrm{K} 1$ in healthy and diseased newborns. Lancet, 1, 1099.

SChLECht, S. AND WeStPHAL, O. 1967. Uber die Herstellung von Antiseren gegen die somatischen (O-) Antigene von Salmonellen. I. Mitteilung: Untersuchungen über Agglutinintiter. Zentbl. Bakt. ParasitKde, I. Abt. Orig., 204, 335.

SCHMid, G., Fromme, I. AND MAYER, H. 1970. Immunochemical studies on core lipopolysaccharides of Enterobacteriaceae of different genera. Eur. J. Biochem., 14, 357.

SmITH, H. 1977. Microbial surfaces in relation to pathogenicity. Bact. Rev., 41, 475.

TAYLOR, P. W. 1975. Genetical studies of serum resistance in Escherichia coli. J. gen. Microbiol., 89, 57.

TAYLOR, P. W. 1976. Immunochemical investigations on lipopolysaccharides and acidic polysaccharides from serum-sensitive and serum-resistant strains of Escherichia coli isolated from urinary-tract infections. J. med. Microbiol., 9, 405.

TAYLOR, P. W. 1978. The effect of the growth environment on the serum sensitivity of some urinary Escherichia coli strains. F.E.M.S. microbiol. Lett., 3, 119. 
TAYLOR, P. W. AND HUGHES, C. 1978. Plasmid carriage and the serum sensitivity of enterobacteria. Infect. Immun., 22, 10.

TAYLOR, P. W., Hughes, C. AND Robinson, M. 1979. Plasmids and the serum resistance of enterobacteria. In Plasmids of medical, environmental and commercial importance, edited by K. N. Timmis and A. Pühler, Elsevier/North Holland Biomedical Press, Amsterdam, p. 135.

TAYLOR, P. W. AND PARTON, R. 1977. A protein factor associated with serum resistance in Escherichia coli. J. med. Microbiol., 10, 225.

TAYLOR, P. W. AND SLEYTR, U. B. 1977. Release of a lysogenic bacteriophage from a smooth urinary $E$. coli strain following magnesium limitation in the chemostat. F.E.M.S. microbiol. Lett., 2, 189.

WaRDLAW, A. C. 1963. The complement-dependent bacteriolytic activity of normal human serum. II. Cell wall composition of sensitive and resistant strains. Can. J. Microbiol., 9, 41.

W ARREN, L. 1959. The thiobarbituric acid assay of sialic acids. J. biol. Chem., 234, 1971.

WESTPHAL, O. AND JANN, K. 1965. Bacterial lipopolysaccharides: extraction with phenol-water and further applications of the procedure. In Methods in carbohydrate chemistry, vol. 5, edited by R. L. Whistler, Academic Press, London, p. 83. 